\title{
SOIL ENZYMATIC ACTIVITY AND NITROUS OXIDE EMISSION FROM LIGHT-TEXTURED SPODOSOL AMENDED WITH BIOCHAR
}

\author{
E.Ya. RIZHIYA1, I.M. MUKHINA', V.E. VERTEBNIY1, J. HORAK², \\ P.Yu. KONONCHUK ${ }^{1}$, Yu.V. KHOMYAKOV ${ }^{1}$
}

\begin{abstract}
${ }^{1}$ Agrophysical Research Institute, Federal Agency of Scientific Organizations, 14, Grazhdanskii prosp., St. Petersburg, 195220 Russia, e-mail alenarizh@yahoo.com (corresponding author), muhinairina1989@gmail.com, verteb22@mail.ru,7911717774@yandex.ru, himlabafi@yandex.ru;

${ }^{2}$ Slovak University of Agriculture, Faculty of Horticulture and Landscape Engineering, Department of Biometeorology and Hydrology, 94976 Slovakia, Nitra, Hospodárska, 7, e-mail jan.horak@uniag.sk
\end{abstract}

ORCID:

Rizhiya E.Ya. orcid.org/0000-0001-7920-867X

Mukhina I.M. orcid.org/0000-0002-6506-9813

Vertebniy V.E. orcid.org/0000-0002-2936-5949

The authors declare no conflict of interests

Received March 28, 2017

Horak J. orcid.org/0000-0003-0078-9083

Kononchuk P.Yu. orcid.org/0000-0003-0449-5189

Khomyakov Yu.V. orcid.org/0000-0002-9149-3247

\section{Abstract}

Soil amendment with biochar has been proposed as a tool to mitigate soil $\mathrm{N}_{2} \mathrm{O}$ emissions by altering soil physical, chemical and biological properties. Little work has been focused on the effect of biochar on the soil enzymatic activity as the most sensitive indicator to diagnose the changes in soil quality. The 90-day laboratory experiment to study the effect of biochar on the dynamics of some soil enzymes and cumulative $\mathrm{N}_{2} \mathrm{O}$ emissions from the loamy sand Spodosol was conducted with the aim to justify the sensitiveness of the enzymes to soil amendments with biochar. The experimental setup was a randomized block design with 9 replicates and included the soil control $(\mathrm{K})$, the soil with biochar (BC), the soil with mineral fertilizer $\left(\mathrm{N}_{16} \mathrm{P}_{16} \mathrm{~K}_{16}, \mathrm{~N}_{90}\right)$ and the soil with fertilizer and biochar mixture $\left(\mathrm{N}_{90}+\mathrm{BC}\right)$. The hydrolases (urease) and oxidoreductases (catalase, peroxidase and polyphenol oxidase) were selected due to their high sensitivity to the changes in the soil quality and the significance in the nitrogen cycle. The results of the experiment have shown that the soil amendment with $10 \mathrm{t} / \mathrm{ha}$ of biochar significantly $(\mathrm{p}<0.05)$ reduced $\left(1.4\right.$-fold) cumulative $\mathrm{N}_{2} \mathrm{O}$ emissions from the soil compared to the $\mathrm{K}$ and $\mathrm{N}_{90}$ treatments. The presence of biochar in the soil had no significant effect on the urease activity, while activity of the catalase, peroxidase and polyphenol oxidase was significantly $(\mathrm{p}<0.05)$ higher $(1.2$ times in average) due to the changes in the physical properties of the soil (aeration in particular). There was high positive correlation between $\mathrm{N}_{2} \mathrm{O}$ flux and catalase activity $\left(r=0.85\right.$ and 0.87 for BC and $\mathrm{N}_{90}+\mathrm{BC}$, respectively). Based on the calculation of the humification coefficient (polyphenol oxidase activity to peroxidase activity) revealed that soil mineralization increased by $10-13 \%$ after soil amendment with BC, compared to the treatments without BC. The soil amendment with biochar significantly changed the red-ox soil conditions. That was reflected in the changes of enzymatic activity, $\mathrm{N}_{2} \mathrm{O}$ emission and mineralization of humic substances. All the studied enzymes, except urease, were sensitive bio-indicators of soil conditions and could be used in the environment assessment methodology for land-use systems with biochar amendments.

Keywords: loamy sand Spodosol, biochar, mineral N-fertilizer, enzymatic activity, urease, catalase, peroxidase, polyphenol oxidase, nitrous oxide emission

Effects of various agricultural practices on the soil (tillage, application of fertilizers and ameliorants) and agricultural crops cause changes in microbiological and, consequently, enzymatic soil activity [1]. The intensity and trends of these biological processes as well as the integrated effect of soil and climatic factors influence the nitrous oxide $\left(\mathrm{N}_{2} \mathrm{O}\right)$ emission which causes major climate changes [2].

It has been established that the application of biochar to soil alters physical and chemical conditions which affect the activities of microorganisms controlling $\mathrm{C}$ and $\mathrm{N}$ flows in the biosphere [3-8]. Obtained reliable data on the effectiveness of reduction in $\mathrm{N}_{2} \mathrm{O}$ emission from sod-podzolic loamy sand soil us- 
ing biochar raises the possibility of its application in light-textured soils, however, the justification of the practice requires clear understanding of occurring process mechanisms, particularly of the natural enzymatic complex properties. Special focus, in our opinion, should be on the catalyzing effect of hydrolases and oxidoreductases [9, 10]. Among the enzyme classes mentioned, there are ureases (EC 3.5.1.5), catalases (EC 1.11.1.6), peroxidases (EC 1.11.1.7) and polyphenol oxidases (EC 1.10.3.1). These enzymes have high sensitivity to various exposures and perform important functions in the organic matter transformation which the $\mathrm{N}$ cycle depends on [11-13]. The urease activity is associated with urea ammonification and nitrogen conversion into the plant-available form. Catalase belongs to oxidation-reduction enzymes. Polyphenol oxidase and peroxidase participate in multistage degradation and synthesis of aromatic organic compounds having an impact on humification [14]. Biological diagnosis of soils based on their enzymatic activity will enable to identify the nature and level of the man-caused impact on the soil cover and reveal mechanisms of interaction between the product applied and the soil.

We are the first to perform the coupled analysis of the biochar impact on $\mathrm{N}_{2} \mathrm{O}$ formation in soil and activity of enzymes participating in the transformation of carbon- and nitrogen-containing substances, and show an essential role of oxidation-reduction enzymes in revealing the mechanisms of biochar action on soil.

The purpose of the model experiments conducted was to assess the biochar effect on $\mathrm{N}_{2} \mathrm{O}$ emission and enzymatic activity of the sod-podzolic loamy sand soil.

Technique. Samples of the sod-podzolic loamy sand soil were taken from a plough layer $(0-28 \mathrm{~cm})$ before the field season of 2016 (biopolygon of Menkovskii Branch of the Agrophysical Institute, Gatchina Region, Leningrad Province), dried at $22{ }^{\circ} \mathrm{C}$ and sieved (through $2 \mathrm{~mm}$ openings). The biochar was produced by the fast anaerobic pyrolysis of soft wood of broad-leaved trees (alder, birch, aspen) at $550{ }^{\circ} \mathrm{C}$. The biochar fraction with particles of $<1 \mathrm{~cm}$ in size was applied to the soil.

The sieved soil (300 g) moistened up to $23 \%$ of the minimum moisture capacity (MMC) were placed into each of $500 \mathrm{ml}$ vegetation vessels with seal caps having rubber stoppers in their centers for air sampling using a syringe. The vessels were preincubated for the first 7 days to reach the balanced state of the microbial community and moisture content. Then, the soil was applied with biochar (B) at the dose of $0.42 \mathrm{~g} /$ vessel that was equivalent to 10 tons of biochar per 1 ha, ammonium nitrate phosphate fertilizer $\mathrm{N}_{16} \mathrm{P}_{16} \mathrm{~K}_{16}\left(\mathrm{~N}_{90}\right)$ at the dose of $0.23 \mathrm{~g} / \mathrm{vessel}(90 \mathrm{~kg} \mathrm{~N} / \mathrm{ha})$ or a mixture of biochar and ammonium nitrate phosphate fertilizer $\left(\mathrm{N}_{90}+\mathrm{B}\right)$. The substrates obtained were mixed uniformly. Soil without biochar and fertilizer was used as control $(\mathrm{K})$ that was preincubated and mixed as well. The samples were compacted to $1.2 \mathrm{~g} / \mathrm{cm}^{3}$ that corresponded to steady-state bulk density of the soil under study in the field conditions. The experiment included 9 replicates with randomized distribution of the samples. The vessels were placed into biological cabinets for incubation at the constant temperature of $28{ }^{\circ} \mathrm{C}$. Throughout the experiment, the soil vessels were held open, they were closed for $30 \mathrm{~min}$ only for air sampling to analyze for $\mathrm{N}_{2} \mathrm{O}$. The soil moisture was maintained on the basis of the vessel weight at the initially set moisture level, the soil was moistened after the air sampling.

Upon biochar and mineral fertilizer application, air sampling was carried out every other day over the first 2 weeks, then 2-3 times a week, and once a week in 60 days. In total, the experiment lasted for 90 days.

$\mathrm{N}_{2} \mathrm{O}$ concentration in the air samples was measured using Fractovap 4130 gas chromatograph (Carlo Erba Strumentazione SpA, Italy) equipped with 
an electron capture detector.

The enzymatic activity dynamics (sampling every 10 days) was studied using standard procedures [13, 14]: the activity of catalase was identified by permanganatometry according to Johnson and Temple, the urease activity was determined photocolorimetrically using the Nessler's reagent, based on the amount of colored ammonia complexes formed during urea hydrolysis; and the activity of peroxidase and polyphenol oxidase was identified photocolorimetrically according to Galstyan technique (1968).

Microsoft Excel and Statistics 8.0 (Stat Soft Inc., USA) software were used to process data. The statistical analysis included calculations of mean $(M)$ and standard deviations $( \pm \mathrm{SD})$, and linear correlation coefficients $(r)$ at $\mathrm{p} \leq 0.05$. The significance of differences in the mean values was assessed by the one-way analysis of variance (ANOVA) and a posteriori analysis based on the Tukey's honestly significant difference test at $\mathrm{p} \leq 0.05$ [15].

Results. The main agrochemical characteristics of the soil at the time of sampling were as follows: $\mathrm{C}_{\text {organic }}-2.4 \% ; \mathrm{N}_{\text {total }}-0.17 \%$; $\mathrm{N}-\mathrm{NO}_{3}-11.2 \mathrm{mg} / \mathrm{kg}$; $\mathrm{N}-\mathrm{NH}_{4}-4.5 \mathrm{mg} / \mathrm{kg}$; movable $\mathrm{P}_{2} \mathrm{O}_{5}-299 \mathrm{mg} / \mathrm{kg}$; movable $\mathrm{K}_{2} \mathrm{O}-97 \mathrm{mg} / \mathrm{kg}$; $\mathrm{pH}_{\mathrm{KCl}} 5.3$; the biochar characteristics were: $\mathrm{C}_{\text {total }}-87.4 \% ; \mathrm{N}_{\text {total }}-0.038 \%$, $\mathrm{H}-28 \mathrm{mg} / \mathrm{g}, \mathrm{pH} 7.6$.

The cumulative emissions of $\mathrm{N}_{2} \mathrm{O}$ calculated for 80 days have shown the significant $(\mathrm{p}<0.05)$ differences among all the experiment treatments (Fig. 1). The application of $\mathrm{N}_{16} \mathrm{P}_{16} \mathrm{~K}_{16}\left(\mathrm{~N}_{90}\right)$ to the soil under study has increased the cumulative emission of $\mathrm{N}_{2} \mathrm{O}$ twice as compared to the soil control, while the biochar application has decreased the cumulative emission 1.4 times both as compared to the soil control and as regard to the soil with the mineral fertilizer.

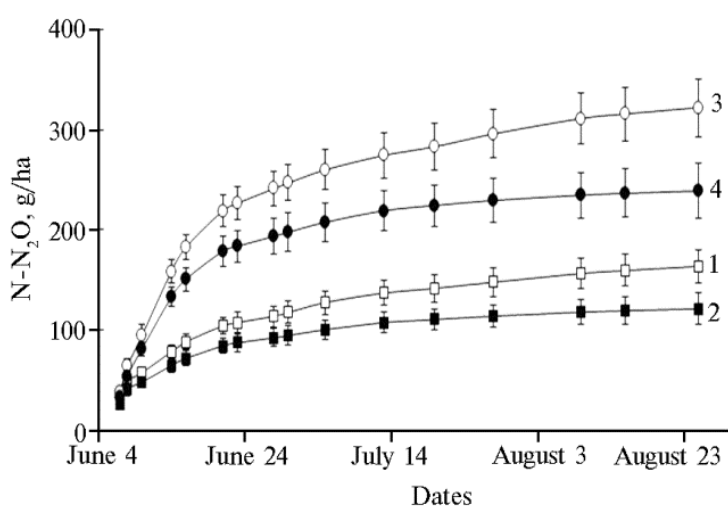

Fig. 1. Cumulative nitrous oxide emission from the sodpodzolic soil samples: soil control (1), when applying biochar (2), fertilizer (ammonium nitrate phosphate fertilizer) (3) and the mixture of biochar and fertilizer (4). The mean $(M)$ and standard deviations $( \pm \mathrm{SD})$ provided (laboratory experiment). amendment with biochar, even when there were $78 \%$ of water-saturated pores, i.e. under anaerobic conditions. The improvement of the air and water regime in soil and a decreased denitrification resulted in the reduction of cumulative $\mathrm{N}_{2} \mathrm{O}$ emission from soils.

It has been also established earlier that biochar contributed to the increase in activity, group and functional diversity of the microbial community in soil [8, 16], stimulated the development of soil molds and aerobic cellulosefermenting bacteria which consumed nitrogen intensively and inhibited the growth of nitrogen-fixing bacteria [17, 18].

The soil amendment with organic, mineral fertilizers and ameliorants 
may change the activity of urease that defines important stages of transformations of nitrogen-containing substances in soil. The experiment results have indicated that, according to the enzyme enrichment assessment of soils [19], the soils studied were described as poor in urease activity (3 to $10 \mathrm{mg}$ of $\mathrm{N}-\mathrm{NH}_{4} / 10 \mathrm{~g}$ of soil per day). The enzyme accumulation dynamics has shown the increase in activity during 30 incubation days with further decrease by the end of the experiment. The application of ammonium nitrate phosphate fertilizer has increased the urease activity significantly $(\mathrm{p}<0.05)(1.6$ times on average) as compared to the soil control, while the application of biochar caused no significant decrease in the urease activity as compared to both the soil control and $\mathrm{N}_{90}$ (Fig. 2). Correlation coefficients $(r)$ between $\mathrm{N}_{2} \mathrm{O}$ emission and urease activity were low (at p < 0.05): $0.51(\mathrm{~K}), 0.38(\mathrm{~B}), 0.62\left(\mathrm{~N}_{90}\right)$, and $0.67\left(\mathrm{~N}_{90}+\mathrm{B}\right)$. In studies of H. Jin [20], it has been found that the soil amendment with biochar may cause decrease in the urease activity that is associated with $\mathrm{pH}$ change (the majority of biochars have neutral $\mathrm{pH}$ ) and high adsorption capacity of biochar.

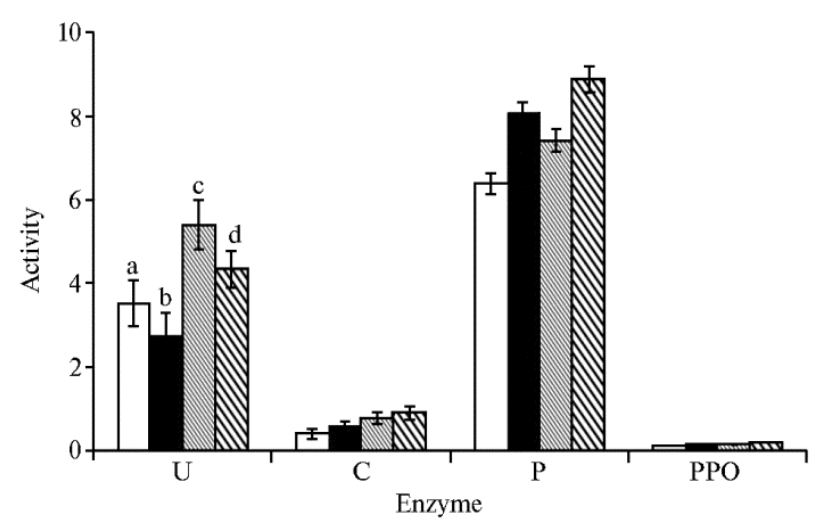

Fig. 2. Enzymatic activity of the sod-podzolic soil in the soil control (a), when applying biochar (b), fertilizer (ammonium nitrate phosphate fertilizer) (c) and mixture of biochar and fertilizer (d): $\mathrm{U}$ urease, $\mathrm{mg}$ of $\mathrm{N}-\mathrm{NH}_{4} / 10 \mathrm{~g}$ of soil per day; $\mathrm{C}$ - catalase, $\mathrm{mg}$ of $\mathrm{KMnO}_{4} / \mathrm{g}$ of soil per $20 \mathrm{~min}$; $\mathrm{P}-$ peroxidase, $\mathrm{mg}$ of purpurogallin/100 g of soil: PPO - polyphenol oxidase, $\mathrm{mg}$ of purpurogallin/100 $\mathrm{g}$ of soil. The mean $(M)$ and standard deviations $( \pm \mathrm{SD})$ provided (laboratory experiment).

The catalase activity in our experiment decreased from the beginning to the end of observation in all treatments studied. The similar trend was also noted in other studies, for example M.A. Razmakhina [21] and E.V. Dadenko [22] reported that the catalase activity in laboratory conditions showed a general decrease trend by the end of the experiment and depended on the air conditions, moisture and bulk density of soils.

As for the enzyme enrichment [19], the soils studied in the experiment were described as extremely poor by their catalase activity $\left(<1 \mathrm{mg}\right.$ of $\mathrm{KMnO}_{4} / 1 \mathrm{~g}$ per $20 \mathrm{~min})$. The soil control contained the minimum amount of the enzyme that varied from 0.89 to $0.23 \mathrm{mg}$ of $\mathrm{KMnO}_{4} / \mathrm{g}$ for $20 \mathrm{~min}$. The application of $\mathrm{N}_{90}$ has increased the catalase activity significantly $(\mathrm{p}<0.001) 1.4$ times on average, and the application of biochar $(\mathrm{p}<0.05)$ has also increased the enzyme activity 1.3 and 1.2 times as compared to the soil control and soil with ammonium nitrate phosphate fertilizer, respectively (refer to Fig. 2). The correlation coefficients between $\mathrm{N}_{2} \mathrm{O}$ emission and catalase activity were high $(\mathrm{p}<0.05)$ : 0.89 $(\mathrm{K}), 0.85(\mathrm{~B}), 0.84\left(\mathrm{~N}_{90}\right)$, and $0.87\left(\mathrm{~N}_{90}+\mathrm{B}\right)$.

The study results have shown that the peroxidase activity was on average 50 times higher than that of polyphenol oxidase, and the biochar application has increased the enzyme activities substantially $(\mathrm{p}<0.05)$ as compared to those in the treatments without biochar. It is more likely to be associated with special aeration conditions provided owing to the porous structure of biochar (in contrast to the samples containing no biochar) [22-24]. However, the correlation coefficients between $\mathrm{N}_{2} \mathrm{O}$ emission and peroxidase activity as well as polyphenol oxidase activity were low (at $\mathrm{p}<0.05$ ): -0.42 and $0.45(\mathrm{~K}),-0.47$ and 0.59 (B), -0.39 and $0.46\left(\mathrm{~N}_{90}\right),-0.47$ and $0.41\left(\mathrm{~N}_{90}+\mathrm{B}\right)$, respectively. 
The polyphenol oxidase activity to peroxidase activity ratio is generally thought to be a conditional coefficient of organic matter humification $\left(\mathrm{C}_{\text {hum }}\right)$, which can, to a certain extent, describe the formation trend of specific humic substance in soil (mineralization or immobilization) [22, 25]. The value of $\mathrm{C}_{\text {hum }}$ calculated by the ratio of the enzyme activity has appeared to be $<1$ in all the experiment treatments, indicating that mineralization of humic substances dominated over their synthesis. The biochar application contributed to insignificant increase in the mineralization, 1.1 times on average, as compared to the soil control and soil with mineral fertilizers.

Thus, when applying biochar (10 t/ha) to the sod-podzolic loamy sand soil, $\mathrm{N}_{2} \mathrm{O}$ emission was significantly $(\mathrm{p}<0.05)$ lower $(1.4$ times on average) than in the control soil and soil with the mineral fertilizer. In this case, the urease activity decreased 1.2 times on average (with no considerable differences from the treatments without biochar). The activity of oxidoreductases under study increased significantly $(\mathrm{p}<0.05)$, i.e. 1.3 times for catalase, 1.2 times for peroxidase and polyphenol oxidase, that was associated with changes in the physical properties of the soil caused by biochar amendment (first of all, aeration) and reflected changes in the oxidation-reduction conditions. The high positive correlation has been established between $\mathrm{N}_{2} \mathrm{O}$ emission and catalase activity $(r=0.85$ and $r=0.87$ for biochar and the mixture of biochar and ammonium nitrate phosphate fertilizer, respectively). The ratio of polyphenol oxidase activity to that of peroxidase provided evidence of enhancing mineralization of humic substances in the presence of biochar. All the studied enzymes, except urease, have appeared to be sensitive bioindicators of soil conditions and can be used for environmental assessment of land-use systems.

\section{REFERENCES}

1. Mishusti n E.N. Mikroorganizmy i produktivnost' zemledeliya [Microorganisms and productivity of arable farming]. Moscow, 1972 (in Russ.).

2. Kude y a rov V.N. Nitrogen cycle and nitrous oxide production. Eurasian Soil Science, 1999, 32(8): 892-901. Available https://elibrary.ru/item.asp?id=13312593. No date.

3. Verheijen F., Jeffery S., B astos A.C., van de r Veld e M., Diafas I. Biochar application to soils. A critical scientific review of effects on soil properties, processes and functions. European Commission, Joint Research Centre, 2010 (doi: 10.2788/472).

4. Van Zwieten L., Kimber S., Morris S., Downie A., Berger E., Rust J., $\mathrm{S} \mathrm{c}$ h e e r C. Influence of biochars on flux of $\mathrm{N}_{2} \mathrm{O}$ and $\mathrm{CO}_{2}$ from Ferrosol. Austr. J. Soil. Res., 2010, 48: 555-568 (doi: 10.1071/SR10004).

5. Lehmann J., Rillig M.C., Thies J., M asie 11 o C.A., Hockaday W.C., C row le y D. Biochar effects on soil biota - a review. Soil Biol. Biochem., 2011, 43: 1812-1836 (doi: 10.1016/j.soilbio.2011.04.022).

6. Zheng H., Wang Z., D eng X., Herbert S., Xing B. Impacts of adding biochar on nitrogen retention and bioavailability in agricultural soil. Geoderma, 2013, 206: 32-39 (doi: 10.1016/j.geoderma.2013.04.018).

7. Go mez J.D., D e nef K., S t e wart C.E., Z heng J., Cotrufo M.F. Biochar addition rate influences soil microbial abundance and activity in temperate soils. Eur. J. Soil Sci., 2014, 65: 28-39 (doi: 10.1111/ejss.12097).

8. Rizhiya E.Ya., B u chkina N.P., Mukhina I.M., B elinets A.S., B a lashov E.V. Pochvovedenie, 2015, 2: 211-220. Available https://elibrary.ru/item.asp?id=22840918. No date (in Russ.).

9. Hochste in L.I., To mlins o n G.A. The enzymes associated with denitrification. Annu. Rev. Microbiol., 1988, 42: 231-261 (doi: 10.1146/annurev.mi.42.100188.001311).

10. M c Carty G.W. Modes of action of nitrification inhibitors. Biol. Fertil. Soils, 1999, 29: 1-9 (doi: 10.1007/s003740050518).

11. Jin K., Sleutel S., Buchan D., De Neve S., Cai D., Gabriels D., Jin J.Y. Changes of soil enzyme activities under different tillage practices in the Chinese Loess Plateau. Soil and Tillage Research, 2009, 104(1): 115-120 (doi: 10.1016/j.still.2009.02.004).

12. Rajapaksha A.U., Vithanage M., Zhang M., Ahmad M., Mohan D., $\mathrm{C}$ h a ng S.X., O k Y.S. Pyrolysis condition affected sulfamethazine sorption by tea waste bio- 
chars. Bioresource Technology, 2014, 166: 303-309 (doi: 10.1016/j.biortech.2014.07.100).

13. Khaziev F.Kh. Sistemno-ekologicheskii analiz fermentativnoi aktivnosti pochv [Ecological assay of soil enzymatic activity]. Moscow, 1982 (in Russ.).

14. K h a z i e v F.Kh. Metody pochvennoi enzimologii [Methods of soil enzymology]. Moscow, 2005 (in Russ.).

15. R: A language and environment for statistical computing. $R$ Foundation for Statistical Computin, Vienna, 2014. Available https://www.r-project.org/. No date.

16. S ig no r D., C e r r i C.E.P., C o n a n t, R. $\mathrm{N}_{2} \mathrm{O}$ emissions due to nitrogen fertilizer applications in two regions of sugarcane cultivation in Brazil. Environ. Res. Lett., 2013, 8(1): 015013 (doi: 10.1088/1748-9326/8/1/015013).

17. Wang C., Lu H., Dong D., D eng H., Strong P.J., Wang H., Wu W. Insight into the effects of biochar on manure composting: evidence supporting the relationship between $\mathrm{N}_{2} \mathrm{O}$ emissions and denitrifying community. Environ. Sci. Technol., 2013, 47(13): 7341-7349 (doi: 10.1021/es305293h).

18. B a i le y V.L., F a n s le r S.J., S m it h J.L., B o lt o n H., Jr. Reconciling apparent variability in effects of biochar amendment on soil enzyme activities by assay optimization. Soil Biol. Biochem., 2010, 43(2): 296-301 (doi: 10.1016/j.soilbio.2010.10.014).

19. Zvy a g i nts ev D.G. Pochva i mikroorganizmy [Soil and microorganisms]. Moscow, 1987 (in Russ.).

20. J i n H. Characterization of microbial life colonizing biochar and biochar-amended soils. PhD diss. Cornell University, Ithaca, 2010. Available https://ecommons.cornell.edu/han-dle/1813/17077. No date.

21. R a z m a k hi n a M.A. Materialy VII Mezhdunarodnoi studencheskoi elektronnoi nauchnoi konferentsii «Studencheskii nauchnyi forum-2015» [Proc. VII Int. eConf. «Student Science Forum2015]. Available http:// www.scienceforum.ru/2015/826/8691. No date (in Russ.).

22. Dadenko E.V., Denisova T.V., Kazeev K.Sh., Kolesnikov S.I. Povolzhskii ekologicheskii zhurnal, 2013, 4: 385-393. Available http://www.sevin.ru/volecomag/issues/2013_4.html\#a5. No date (in Russ.).

23. B a ch C.E., W a r no ck D.D., V a n Horn D.J., We intraub M.N., S i n s ab a u g h R.L., A 11 i s o n S.D., G e r m a n D.P. Measuring phenol oxidase and peroxidase activities with pyrogallol, L-DOPA, and ABTS: Effect of assay conditions and soil type. Soil Biol. Biochem., 2013, 67: 183-191 (doi: 10.1016/j.soilbio.2013.08.022).

24. Kolb S.E., Fermani ch K.J., D o r n b u s h M.E. Effect of charcoal quantity on microbial biomass and activity in temperate soils. Soil Sci. Soc. Am. J., 2009, 73: 1173-1181 (doi: 10.2136/sssaj2008.0232).

25. Gul'k o A.E., Khazi e v F.Kh. Pochvovedenie, 1992, 11: 55-68 (in Russ.). 